\title{
Participation of heparin binding proteins from the surface of Leishmania (Viannia) braziliensis promastigotes in the adhesion of parasites to Lutzomyia longipalpis cells (Lulo) in vitro
}

Luzia Monteiro de Castro Côrtes', Mirian Claudia de Souza Pereira², Franklin Souza da Silva', Bernardo Acácio Santini Pereira ${ }^{1}$, Francisco Odêncio de Oliveira Junior ${ }^{1,2}$, Renata Oliveira de Araújo Soares ${ }^{1}$, Reginaldo Peçanha Brazil ${ }^{3}$, Leny Toma ${ }^{5}$, Carolina Meloni Vicente ${ }^{5}$, Helena Bonciani Nader ${ }^{5}$, Maria de Fátima Madeira ${ }^{4}$, Felio J Bello ${ }^{6}$ and Carlos Roberto Alves ${ }^{1 *}$

\begin{abstract}
Background: Leishmania (V.) braziliensis is a causative agent of cutaneous leishmaniasis in Brazil. During the parasite life cycle, the promastigotes adhere to the gut of sandflies, to avoid being eliminated with the dejection. The Lulo cell line, derived from Lutzomyia longipalpis (Diptera: Psychodidae), is a suitable in vitro study model to understand the features of parasite adhesion. Here, we analyze the role of glycosaminoglycans (GAGs) from Lulo cells and proteins from the parasites in this event.

Methods: Flagellar $\left(F_{f}\right)$ and membrane $\left(M_{f}\right)$ fractions from promastigotes were obtained by differential centrifugation and the purity of fractions confirmed by western blot assays, using specific antibodies for cellular compartments. Heparin-binding proteins (HBP) were isolated from both fractions using a HiTrap-Heparin column. In addition, binding of promastigotes to Lulo cells or to a heparin-coated surface was assessed by inhibition assays or surface plasmon resonance (SPR) analysis.
\end{abstract}

Results: The success of promastigotes subcellular fractionation led to the obtainment of $\mathrm{F}_{\mathrm{f}}$ and $\mathrm{M}_{\mathrm{f}}$ proteins, both of which presented two main protein bands ( 65.0 and $55.0 \mathrm{kDa}$ ) with affinity to heparin. The contribution of HBPs in the adherence of promastigotes to Lulo cells was assessed through competition assays, using HS or the purified HBPs fractions. All tested samples presented a measurable inhibition rate when compared to control adhesion rate ( $17 \pm 2.0 \%$ of culture cells with adhered parasites): $30 \%$ (for $\mathrm{HS} 20 \mu \mathrm{g} / \mathrm{ml}$ ) and $16 \%$ (for HS $10 \mu \mathrm{g} / \mathrm{ml}$ ); HBP M $\mathrm{M}_{\mathrm{f}}(35.2 \%$ for $10 \mu \mathrm{g} / \mathrm{ml}$ and $25.4 \%$ for $20 \mu \mathrm{g} / \mathrm{ml})$ and HBP F $F_{f}(10.0 \%$ for $10 \mu \mathrm{g} / \mathrm{ml}$ and $31.4 \%$ for $20 \mu \mathrm{g} / \mathrm{ml})$. Additionally, to verify the presence of sulfated GAGs in Lulo cells surface and intracellular compartment, metabolic labeling with radioactive sulfate was performed, indicating the presence of an HS and chondroitin sulfate in both cell sections. The SPR analysis performed further confirmed the presence of GAGs ligands on L. (V.) braziliensis promastigote surfaces.

Conclusions: The data presented here point to evidences that HBPs present on the surface of L. (V.) braziliensis promastigotes participate in adhesion of these parasites to Lulo cells through HS participation.

Keywords: L. (V.) braziliensis, Promastigotes, Lulo cells, Glycosaminoglycans, Surface plasmon resonance

\footnotetext{
*Correspondence: calves@ioc.fiocruz.br

'Laboratório de Biologia Molecular e Doenças Endêmicas, Av. Brasil 4365, Rio de Janeiro - CEP 21040-360, Brazil

Full list of author information is available at the end of the article
} 


\section{Background}

The leishmaniases are vector-borne anthropozoonotic diseases, which are caused by parasites of the genus Leishmania. These parasites are inoculated into their mammal hosts during the blood meal of the phlebotomine sandflies, which are widely spread in tropical and subtropical regions (http://www.who.int/leishmaniasis/en/). When Leishmania parasites infect human hosts, they can induce an array of clinical manifestations, varying from tegumentary (mucocutaneous, cutaneous and diffuse) to visceral infections. In Brazil, Leishmania (Viannia) braziliensis is the main species related to the cutaneous and mucocutaneous forms of the disease [1], and its primary vectors are Lutzomyia (Nyssomyia) intermedia and Lutzomyia (Nyssomyia) whitmani [2]. The difficulty of controlling the disease in endemic areas is a consequence of the absence of effective vaccines or drug therapies against the different species of Leishmania, a consequence of the complexity of host-pathogen interactions [3].

During their life cycle, these parasites undergo distinct morphological stages, as promastigotes in the sandfly host and amastigotes in the mammalian host, each one adapted to its microenvironment [4]. Such adaptations are pivotal for a successful completion of the parasite life cycle. For example, the development of promastigotes, coming from a contaminated blood meal, to the procyclical form in the peritrophic matrix formed in the gut of the sandfly host after feeding [5], may be related to parasites escaping from this matrix and adhering to the microvilli of epithelial cells in the stomach [6]. This is an example of an essential step in maintainance of the cycle and may be a factor in the selection of infective and non-infective strains [5]. The promastigotes living within the sandfly gut, present a flagellum that is responsible for their motility and, also, plays a role in the attachment to sandfly gut [7]. Although several organic components of Leishmania spp have been the subject of many studies for understanding the biological cycle of these parasites in the mammalian, studies about the role of such components in the interaction with the insect vector are less abundant. Parasite surface components that have been shown to act in parasite-host interaction include glycoconjugates from promatigotes, as the glycosylated major surface protein of $63 \mathrm{kDa}$ (gp63) [8], lipophosphoglycan (LPG) or proteophosphoglycan (PPG) [9]. It has been described that the down-regulation of gp63 in a Leishmania (Leishmania) amazonensis clone adversely affects its development in the neotropical sand fly, Lutzomyia longipalpis. A possible role for LPG in the parasite interaction with the intestinal epithelium of sandfly has been proposed [10-12], where this molecule would prevent the promastigotes to be excreted with the dejection, while PPG in filamentous form (fPPG) seems to play a mechanical role, blocking the foregut and, thus, inducing regurgitation, which is advantageous for parasite infection of mammal host [13].

The state of the art on Leishmania spp life cycle studies includes a recent discussion on the use of insect cell lines to understand the fine interactions that occur between these parasites and their invertebrate hosts. For example, Lulo cells, a cell lineage derived from Lutzomyia longipalpis, are a potential in vitro model to understand the features of the infection-related adhesion phenomena [14]. These models are suitable for analyzing the effects of interactions between surface molecules from both parasite (e.g., gp63, LPG, PPG etc.) and host (e.g., proteoglycans) in the infection evolution.

Proteoglycans are characterized by a core protein that is covalently linked to glycosaminoglycan (GAG) side chains and are components of the extracellular matrix of insect [15,16] and mammalian tissues [17]. The GAGs structure shows linear polysaccharides constituted by repeating units of disaccharides containing uronic acid and a hexosamine; these disaccharides may vary in the type of hexosamine, hexose or hexuronic acid unit. The sulfated GAGs are classified as heparin [2-O-sulfo- $\beta$-Dglucuronic acid (GlcUA-2 S) or 2-O-sulfo- $\alpha$-L-iduronic acid (IdoUA-2 S) associated to $\mathrm{N}$-acetylglucosamine (GlcNAc) or N-sulfoglucosamine (GlcNS)], heparan sulfate [GlcUA, IdoUA or IdoUA-2 S associated to GlcNAc or GlcNS], chondroitin sulfate [GlcUA associated to Nacetylgalactosamine (GalNAc)], dermatan sulfate [GlcUA or IdoUA associated to GalNAc] and keratan sulfate [galactose (Gal) associated to GlcNAc], [18]. GAGs, as heparan sulfate and dermatan sulfate, present in host tissue have been reported to influence the Leishmania spp life cycle as well as of other parasites [19].

Although heparin is not found on the cell surface of the host, this GAG has been commonly used as a tool for studies on pathogen-host cell interactions. It has been previously shown that amastigotes of $L$. (L.) amazonensis and Leishmania (Leishmania) major have a greater ability to bind to heparin than promastigotes of these same species [20]. In addition, GAGs, including heparin, can induce the proliferation of $L$. (L.) major in the gut of the insect vector, increasing the parasite load of experimentally infected insects [21].

There is evidence that heparin-binding proteins (HBPs) present on the surface of Leishmania spp may play important roles in the parasites life cycle, defining the success of parasite attachment to and invasion of tissues of the mammalian and invertebrate hosts. In the parasite species in which these proteins have been identified, it was observed that HBPs present activity as adhesion proteins, and can promote the internalization and signaling in the host cells [22]. Experiments performed with promastigotes of Leishmania (Leishmania) donovani showed that about 860,000 units of these proteins are present on the surface 
of the parasite and that they are able to induce inhibition of protein kinase $\mathrm{C}$ activity in the host, through the binding to heparin [23,24]. Also, the expression of HBPs in $L$. (L.) donovani is related to the infective forms of this parasite: HBPs are predominant in stationary-phase promastigotes and successive culture passages of these parasites lead to a loss of the ability to bind to the heparin [25].

Previous reports from our group indicate that two HBPs $(65.0$ and $54.5 \mathrm{kDa})$ from $L$. (V.) braziliensis promastigotes recognize several molecules in the gut of $L u$. intermedia and $\mathrm{Lu}$. whitmani [26]. Both proteins are localized in the flagellar and membrane domain of the promastigotes but only the $65.0 \mathrm{kDa} \mathrm{HBP}$ presents metallo proteinase-like activity. Surface plasmon resonance analysis also demonstrated high-affinity binding between heparin and HBPs from the flagellar domain, forming a stable complex [27].

Focusing on fulfilling the lack of information about the interaction of Leishmania spp promastigotes and insect cell lines, as Lulo cells, we present the first evidence that HBPs from $L$. $(V$.) braziliensis promastigotes can be involved in parasite adhesion to these cells by a specific receptor.

\section{Methods}

\section{Chemicals and reagents for culture}

Schneider's medium, Dulbecco's Modified Eagle Media (DMEM), detergents [Tween 20, and 3-[(3-cholamidopropyl)-dimethylammonium]- 1-propanesulfonate (CHAPS)], heparin sodium salt, biotinylated heparin, bovine serum albumin (BSA), 1,3-diaminepropane acetate, penicillin, streptomycin, Horseradish peroxidase (HRP) - conjugated goat anti-mouse IgG (anti-rabbit and anti-mouse HRP) were acquired from Sigma-Aldrich Chemical Co. (St. Louis, MO, USA). Heparin-Sepharose column (HiTrapHeparin; $1.5 \times 2.5 \mathrm{~cm}$ ) was acquired from GE Healthcare. Fetal calf serum (FCS) was acquired from Cultilab S/A (Brazil). Electrophoresis reagents were acquired from BioRad Laboratories Inc. (US). Pre-Stained ${ }^{\mathrm{TM}}$ Plus Protein Ladder was acquired from Fermentas Life Sciences (US). Amicon Centriprep YM-10 filter devices were acquired from Millipore (Billerica Inc, MA, USA). Anti-Na+/K+ ATPase rabbit antibody was acquired from Abcam (Cambridge, MA, USA). Anti-glyceraldehyde-3-phosphate dehydrogenase (anti-GAPDH) mouse monoclonal antibody was acquired from Imgenex (San Diego, CA, USA). Chemiluminescence luminol reagent-ECL kit was acquired from Santa Cruz Biotechnology, Inc. (Santa Cruz, CA, USA). ${ }^{35} \mathrm{~S}_{-} \mathrm{Na}_{2} \mathrm{SO}_{4}$ was purchased from IPEN (São Paulo, SP, Brazil). Chondroitin 4-sulfate from whale cartilage was purchased from Seikagaku America, USA. Heparan sulfate from bovine pancreas was obtained from Opocrin Research Laboratories, Modena, Italy. Pronase and cetyltrimethylammonium bromide was from Merck,
Darmstadt, Germany. All other reagents were of analytical grade or better.

\section{Parasites}

Infective promastigotes of $L$. (V.) braziliensis (MCAN/ $\mathrm{BR} / 1998 / 619)$ were maintained at $28^{\circ} \mathrm{C}$ as a stock culture in Novy, MacNeal and Nicolle medium and subcultured every 4 days. Promastigote cultures were grown in Schneider's medium supplemented with $10 \%$ heatinactivated FCS until a density of $1 \times 10^{8}$ cells $/ \mathrm{mL}$.

\section{Subcellular fractionation}

Subcellular fractions enriched for flagella or surface membranes were obtained by centrifuging fractionation as previously described [27]. Promastigotes were washed twice by centrifugation $\left(3,800 \times \mathrm{g}, 10 \mathrm{~min}, 4^{\circ} \mathrm{C}\right)$ in phosphate-buffered saline ( $\mathrm{pH} 7.2$ ), $\mathrm{PBS}$, and then again washed twice in $10 \mathrm{mM}$ Tris- $\mathrm{HCl}(\mathrm{pH} 7.2)$ buffer containing $1 \mathrm{M} \mathrm{NaCl}, 0.2 \mathrm{M} \mathrm{K}_{2} \mathrm{HPO}_{4}$ and $0.5 \mathrm{M} \mathrm{MgCl}_{2}$. The cell pellet was then resuspended in $10 \mathrm{mM}$ Tris$\mathrm{HCl}$ (pH 7.5) containing $0.05 \mathrm{M}$ sucrose $(10 \mathrm{~mL} / \mathrm{g}$ of cells) and disrupted in 1\% CHAPS with 40 to 80 strokes in a Dounce-type homogenizer, following addition of sucrose to a final concentration of $0.25 \mathrm{M}$. Cells lysates were centrifuged $\left(10 \mathrm{~min}, 4,300 \times \mathrm{g}, 4^{\circ} \mathrm{C}\right)$ and the supernatants were collected and centrifuged again (15 min, $12,000 \times \mathrm{g}, 4^{\circ} \mathrm{C}$ ). The final pellet constituted the flagellar fraction $\left(\mathrm{F}_{f}\right)$, whereas the supernatant was centrifuged again $\left(45 \mathrm{~min}, 35,000 \times \mathrm{g}, 4^{\circ} \mathrm{C}\right)$ to obtain the pellet that constituted the membrane fraction $\left(\mathrm{M}_{f}\right)$.

\section{Affinity chromatography}

Heparin binding proteins were isolated from soluble proteins of $\mathrm{F}_{\mathrm{f}}\left(\mathrm{HBP} \mathrm{F}_{f}\right)$ or $\mathrm{M}_{\mathrm{f}}\left(\mathrm{HBP} \mathrm{M}_{f}\right)$ using a HiTrapHeparin column previously equilibrated with $10 \mathrm{mM}$ sodium phosphate $\mathrm{pH}$ 7.0. The bound proteins were eluted from the column using the equilibrium buffer containing of $2.0 \mathrm{M} \mathrm{NaCl}$, as previously described [27]. The eluted fractions were concentrated using a Centriprep filter device, and the protein concentration was determined as previously described [28].

\section{Denaturant electrophoresis}

Soluble proteins $(40 \mu \mathrm{g})$ were resolved using $12 \%$ sodium dodecyl sulfate-polyacrylamide gel electrophoresis (SDS-PAGE) and silver staining, as previously described $[29,30]$. Electrophoresis was performed at $25^{\circ} \mathrm{C}$ in a Mini Protean II system (BioRad Laboratories, US).

\section{Western blot assays}

For western blot assays, sample proteins $(40 \mu \mathrm{g})$ were resolved using SDS-PAGE and, then, transferred onto $0.22 \mu \mathrm{m}$ nitrocellulose membranes. Non-specific binding sites were blocked $\left(4^{\circ} \mathrm{C}\right.$ for $\left.16 \mathrm{~h}\right)$ using a solution of $5 \%$ 
skimmed milk (w/v) in PBS with the addition of $0.5 \%$ Tween 20. The blots were washed six times with PBS containing $0.05 \%$ Tween 20 (PBST) and incubated (1 h, $25^{\circ} \mathrm{C}$ ) with primary antibodies [anti- $\mathrm{Na}+/ \mathrm{K}+$ ATPase (1:500) or anti-GAPDH (1:100)], diluted in PBST. After six washes with PBST, the blots were incubated $\left(1 \mathrm{~h}, 25^{\circ}\right.$ C) with anti-rabbit HRP (1:2500) or anti-mouse HRP (1:2000) diluted in PBST. The blots were once again washed as described above and the antibody binding was revealed by a chemiluminescence kit.

\section{Lulo cell line}

The insect epithelioid cell line Lulo was cultured in a 1:1 mix of L15 (Leibovitz 1963) and Grace media supplemented with $10 \% \mathrm{FCS}$, penicillin $(100 \mathrm{U} / \mathrm{mL})$ and streptomycin $(100 \mu \mathrm{g} / \mathrm{mL})$ at $28^{\circ} \mathrm{C}$. The cells were seeded on coverlips to a final number of $2 \times 10^{5}$ cells per well and grown to semiconfluent monolayers prior to interaction assays with parasites [14].

\section{Lulo cell metabolic labeling with radioactive sulfate}

Lulo cells were maintained in culture medium free of sulfate for $24 \mathrm{~h}$ and then subjected to incorporation of ${ }^{35} \mathrm{~S}_{-} \mathrm{Na}_{2} \mathrm{SO}_{4}(150 \mathrm{mCi} / \mathrm{mL})$ in DMEM supplemented with 5\% FBS and 10\% horse serum (which have been dialyzed to remove the non-labeled sulfate). After $24 \mathrm{~h}$ incubation $\left(28^{\circ} \mathrm{C}\right)$ with the labeled sulfate, the culture medium was removed and the cells were washed twice in PBS. In order to investigate the presence of GAGs at the cell surface, the cells were first detached from the dish with PBS containing 0.025\% EDTA for $10 \mathrm{~min}$. After centrifugation, the cell pellet was treated with $1 \mathrm{ml}$ solution of $0.2 \%$ trypsin / $0.02 \%$ EDTA in PBS for $5 \mathrm{~min}$ (Cultilab, Campinas, SP) to remove the cell surface proteoglycans. Immediately, medium containing serum was added to neutralize trypsin. Following centrifugation, the supernatant was considered cell surface, and the pellet, cellular extract. The cell pellet was then lysed by treatment with $3.5 \mathrm{M}$ urea in PBS. Proteoglycans from the three compartments (medium, cell surface and cell extracts) were precipitated with 3 vol. of ethanol (18 h, $20^{\circ} \mathrm{C}$ ) in the presence of $200 \mu \mathrm{g}$ of chondroitin 4-sulfate as a carrier. The pellets were dried and incubated $(24 \mathrm{~h}$, $\left.37^{\circ} \mathrm{C}\right)$ with pronase $(12 \mathrm{mg} / \mathrm{mL})$ in $0.05 \mathrm{M}$ Tris- $\mathrm{HCl}, \mathrm{pH}$ 8.0. This GAG suspension was boiled $\left(10 \mathrm{~min}, 100^{\circ} \mathrm{C}\right)$ and then dialyzed for $24 \mathrm{~h}$ with at least four changes of distilled water. Labeled GAGs were dried again and resuspended in $1 \mathrm{~mL}$ of water.

\section{GAGs and enzymatic analysis}

$5 \mu$ of ${ }^{35}$ S-GAGs' samples were incubated with chondroitinases $\mathrm{AC}$ and $\mathrm{ABC}$, and heparinase II (Sigma-Aldrich, St. Louis, MO, USA), according to the manufacturer's instructions. The samples were applied to agarose gel slabs in $0.05 \mathrm{M}$ 1,3-diaminepropane acetate buffer, pH 9.0 [31]. After electrophoresis, the gels were incubated $\left(1 \mathrm{~h}, 25^{\circ} \mathrm{C}\right)$ with $0.2 \%$ cetyltrimethylammonium bromide, to induce GAGs precipitation. The gels were dried, and standard GAGs were stained with toluidine blue. To quantify the radiolabeled GAGs in the gel, a drop of known quantity of radioactive sulfate was applied and dried again. ${ }^{35} \mathrm{~S}$-radiolabeled GAGs, resistant to the enzymes, were visualized as bands, after exposure to a screen for five days, and identified using the image analysis system Cyclone (Storage Phosphor System-Packard Instrument).

\section{Lulo cells-Leishmania interaction}

To evaluate the effect of HS or the HBPs fractions in the adherence of promastigotes to Lulo cells two different protocols were used: a) L.(V.) braziliensis promatigotes in a concentration of $4 \times 10^{7}$ cells $/ \mathrm{mL}$, corresponding to 10:1 parasites/cells were pre-incubated $\left(1 \mathrm{~h}, 4^{\circ} \mathrm{C}\right)$ with $\mathrm{HS}$ $(20 \mu \mathrm{g} / \mathrm{mL}$ and $10 \mu \mathrm{g} / \mathrm{mL})$, and then added to a semi confluent monolayer of Lulo cells; or, b) Lulo cells, in semi confluent monolayer, were incubated for $1 \mathrm{~h}$ with parasite proteins, $\left(20 \mu \mathrm{g} / \mathrm{ml} \mathrm{HBP} \mathrm{F}_{f}\right.$ or $\left.10 \mu \mathrm{g} / \mathrm{ml} \mathrm{HBP}_{f}\right)$ prior to the addition of parasites to the culture wells ( $4 \times 10^{7}$ cells/ $\mathrm{mL}$ ). Subsequently, the Lulo cells/parasites cultures were kept in Grace/L-15 media for $2 \mathrm{~h}$ at $28^{\circ} \mathrm{C}$. The chambers were extensively washed with PBS to remove nonadherent parasites, fixed with methanol and stained with Giemsa. The number of adherent promastigotes was determined by light microscopy examining 300 cells per well, and expressed as a relation of adhered parasites per 100 cells. Analysis was performed in triplicate.

\section{Binding assays by surface plasmon resonance (SPR)}

SPR assays were performed using sensor chip with a carboxyl surface coated with neutravidin (Biocap; Nomadics, USA), as previously described [27]. Briefly, the chip surface was covered with biotinylated heparin $(0.5 \mu \mathrm{g})$ and used in interaction with HBPs fractions $(2 \mu \mathrm{g})$, BSA (0.1 $0.001 \mu \mathrm{g})$ or whole promatigotes $\left(1.4 \times 10^{5}\right.$ cells $)$. To perform inhibition assays, promastigotes or HBPs fractions were pre-incubated $\left(2 \mathrm{~h}, 4^{\circ} \mathrm{C}\right)$ with different concentrations of HS $(0.1 \mu \mathrm{g}-0.001 \mu \mathrm{g})$. Prior to interaction with the sensor chips surface, the promastigotes were fixed $\left(1 \mathrm{~h}, 4^{\circ} \mathrm{C}\right)$ with $1 \%$ paraformaldehyde and washed three times by centrifugation $\left(800 \times \mathrm{g}, 10 \mathrm{~min}, 4^{\circ} \mathrm{C}\right)$ in PBS. SPR assays were performed at $25^{\circ} \mathrm{C}$ with $100 \mu \mathrm{L}$ of material injected under a flow rate of $10 \mu \mathrm{L} / \mathrm{min}$. The binding assays were performed in PBS and registered in real time using a sensorgram, where changes in the SPR angle $(\theta$ spr) were measured as arbitrary resonance units (RU). Resonance signals of the samples were analyzed after subtraction of the RU values from the reference channel, to avoid methodology artifacts. SPR experiments were conducted in an optical biosensor SensiQ Pioneer (Icx 
Nomadics, USA) and the data were analyzed using Qdat software (Icx Nomadics, USA).

\section{Statistical analysis}

To compare results Student's test was applied, assuming equal variance between samples. Data matrices were considered statistically distinct when p-value was lower than 0.05 .

\section{Results}

Two subcellular fractions from $L$. (V.) brasiliensis were characterized in this manuscript. The protein profiles of flagellar $\left(\mathrm{F}_{\mathrm{f}}\right)$ and membrane $\left(\mathrm{M}_{\mathrm{f}}\right)$ fractions, as well as their corresponding heparin-binding subfractions (HBP $F_{\mathrm{f}}$ and $\mathrm{HBP} \mathrm{M}_{\mathrm{f}}$ ), were analyzed by SDS-PAGE revealing complex features, with proteins varying from $17 \mathrm{kDa}$ to $115 \mathrm{kDa}$. The analysis of isolated proteins from HBP $\mathrm{F}_{\mathrm{f}}$ and $\mathrm{HBP} \mathrm{M}_{\mathrm{f}}$, using affinity column, showed two main protein bands, 65.0 and $55.0 \mathrm{kDa}$, for both fractions, as revealed by silver staining (Figure 1A).

The effectiveness of the employed subcellular fractionation technique to separate flagella $\left(\mathrm{F}_{f}\right)$ and membrane $\left(\mathrm{M}_{f}\right)$ fractions was confirmed during our study. Western blot analyses (Figure 1B) indicated that the obtained $\mathrm{F}_{f}$ and $\mathrm{M}_{f}$ fractions were enriched with $\mathrm{Na} / \mathrm{K}+$ ATPase ( $80 \mathrm{kDa}$ protein band), which is a typical protein of membrane and flagella. Additionally, the levels of GAPDH protein $(36 \mathrm{kDa})$, a known cytosolic contaminant were

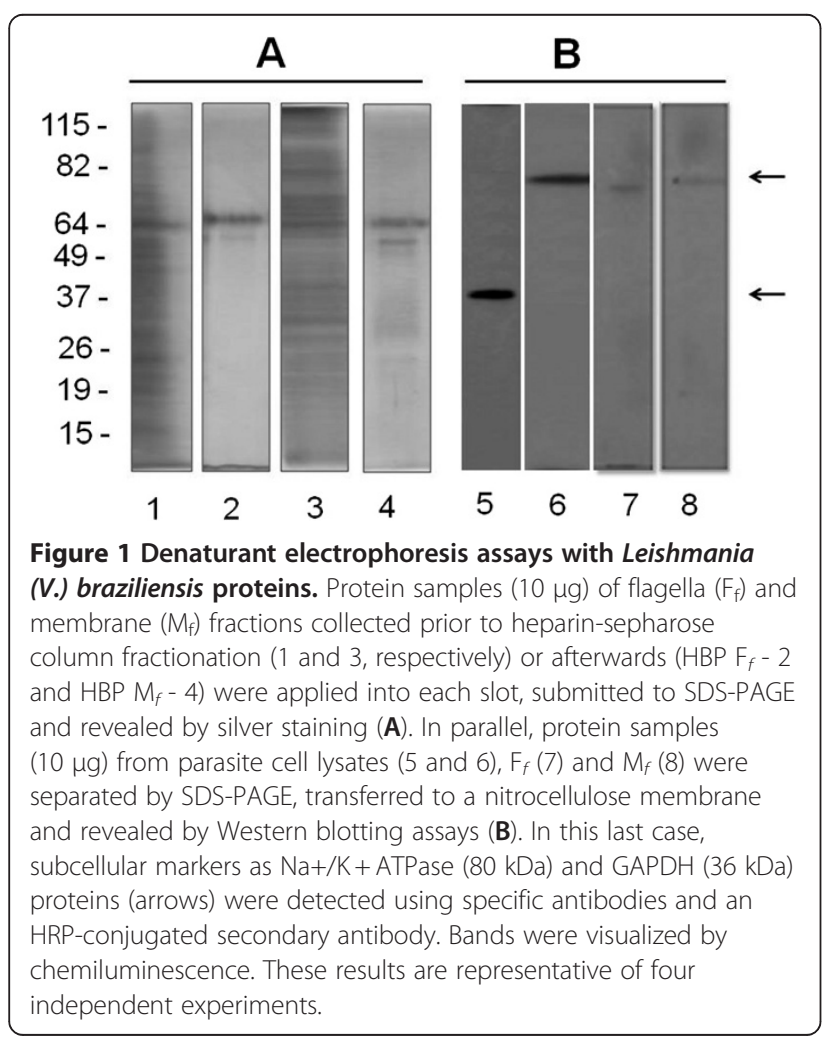

undetectable in the samples, thus indicating their purity. Both proteins were detected in the extract from whole parasite, showing that these proteins can be found in the parasite (Figure 1B).

Characterization of $\mathrm{F}_{f}$ and $\mathrm{M}_{f}$ was performed by detecting typical organelles of these cellular components, as flagellum fragments or spherical membrane-bound vesicles, respectively, using transmission electron microscopy, as previously described (data not shown) [27]

To analyze whether GAGs were expressed by Lulo cells in vitro and, thus, would be able to influence parasite adhesion, experiments for the detection of radioactive labeled GAGs were carried out. We investigated GAGs from cell-secreted material in the growth medium, cell extracts and most importantly, cell surface. The GAGs were metabolically labeled by adding radioactive sulfate $\left(\left[{ }^{35} \mathrm{~S}\right]-\mathrm{Na}_{2} \mathrm{SO}_{4}\right)$ to cell growth medium and, afterwards purified samples from these compartments were analyzed by agarose gel electrophoresis for the presence of radioactivity. After $24 \mathrm{~h}$ in culture, Lulo cells expressed both heparan sulfate and chondroitin sulfate (Figure $2 \mathrm{~A}$ and $\mathrm{B}$ ). The presence of these molecules on cell surfaces was further confirmed by treating GAGs from each compartment with heparinase II and chondroitinase $\mathrm{AC}$ and $\mathrm{ABC}$ (Figure $2 \mathrm{~A}$ ).

Further, we addressed the question whether heparan sulfate (HS) interaction with the parasites may be involved in their adhesion to host cell (Figure 3). To assess the role of HS in the adhesion of promastigotes to Lulo cells, a competition assay was performed, where promastigotes were treated with HS prior to interaction with Lulo cells. In the control assays performed with Lulo cell monolayers pre-incubated or not with BSA $(20 \mu \mathrm{g})$, the percentage of adhered parasites was $17 \pm(2.0)$. The quantitative data revealed a significant decrease in the number of adhered promastigotes/100 cells: a reduction of $30 \%$ (for HS $20 \mu \mathrm{g} / \mathrm{ml} ; \mathrm{p}=0.0025$ ) and $16 \%$ (for HS10 $\mu \mathrm{g} / \mathrm{ml} ; \mathrm{p}=0.0025$ ), when compared to the control (Figure $3 \mathrm{~A}$ ). Also, preincubation of Lulo cell monolayers with $\mathrm{HBP}_{f}$ or $\mathrm{HBP}_{M}$ was able to induce a reduction in the adhesion rates, when compared to the control: $35.2 \%$ (for $\mathrm{HBP} \mathrm{M}_{\mathrm{f}} 10 \mu \mathrm{g}$; $\mathrm{p}=0.0018$ ), $25.4 \%$ (for HBP $\mathrm{M}_{\mathrm{f}} 20 \mu \mathrm{g} ; \mathrm{p}=0.0028$ ), $10.0 \%$ (for $\mathrm{HBP}_{\mathrm{f}} 10 \mu \mathrm{g} ; \mathrm{p}=0.066$ ) and 31.4\% (for HBP F $20 \mu \mathrm{g}$; $\mathrm{p}=0.0071$ ), (Figure $3 \mathrm{~B}$ ).

Complementary to the data obtained from the radioactive labeling assays, it was also possible to assess the presence of GAGs ligands on the surface of $L$. (V.) braziliensis promastigotes through the SPR assays. The binding sensorgram graphs, after the injection of parasites onto a chip surface functionalized with heparin indicated resonance units (RU) values of 80 and 12, respectively (Figure 4). The specificity of this binding was confirmed by additional SPR assays, in which promastigotes were incubated with increasing concentrations of HS prior to 


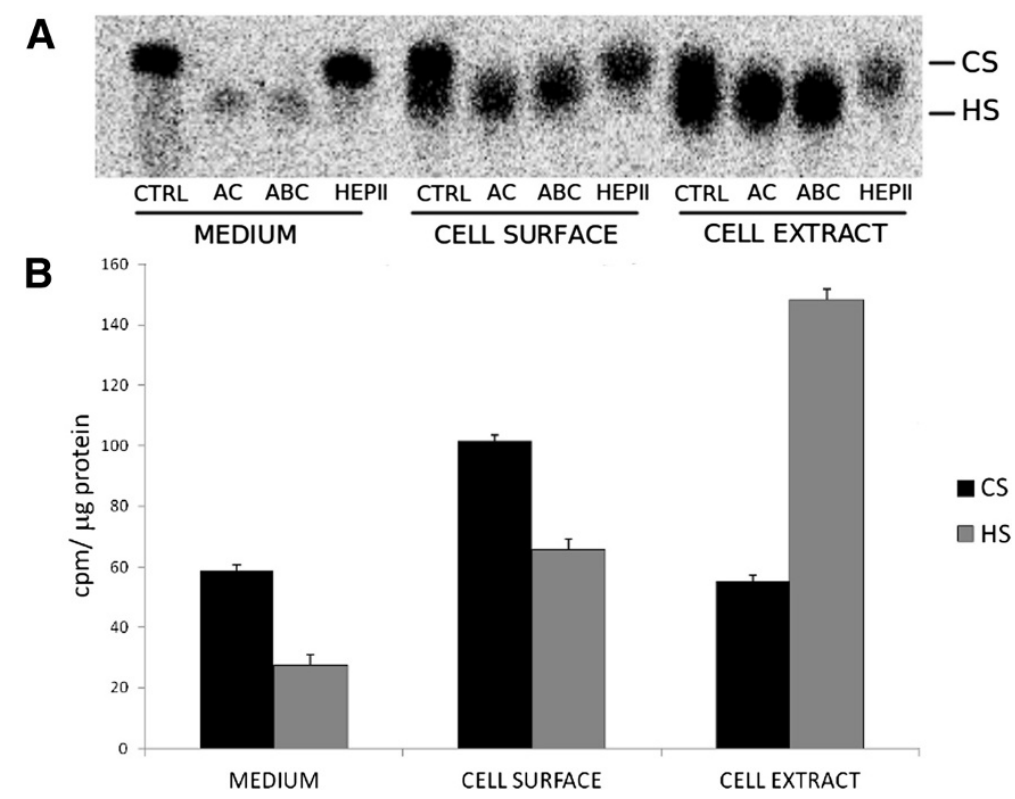

Figure 2 Quantification and identification of sulfated glycosaminoglycans in Lulo cells. After metabolic labeling of Lulo cells with ${ }^{35} \mathrm{~S}_{-} \mathrm{Na}_{2} \mathrm{SO}_{4}$, cell extract, cell surface and cell culture medium were subjected to enzymatic degradation and afterwards to gel electrophoresis in $0.6 \%$ agarose. The bands were identified using an image analysis system, the Cyclone ${ }^{\circledR}$ Storage Phosphor System-Packard Instrument (A). Quantification was performed by densitometry with Opti-Quanti Software and expressed as cpm/mg protein (B). Defined quantities of nonlabeled GAGs (chondroitin sulfate - CS; heparan sulfate - HS) were used as standard control; CTRL - incubation control with buffer; AC chondroitinase AC; ABC - chondroitinase ABC; HEP II - heparinase II.

injection on the chip. In these assays, it was possible to observe a significant inhibition $(\mathrm{p}=0.001)$ of promastigotes binding to immobilized heparin, with RU values decreasing by $38 \%$ when parasites were incubated with $0.1,0.01$ and $0.001 \mu \mathrm{g} / \mathrm{ml}$ of HS (Figure 4).

The binding potential of HBP $\mathrm{F}_{f}$ and $\mathrm{HBP} \mathrm{M}_{f}$ to immobilized heparin was also assessed. The results show that the binding of these fractions to immobilized heparin (approximately $70 \mathrm{RU}$ ) is inhibited by incubation with $\mathrm{HS}$ $(0.1,0.01$ and $0.001 \mu \mathrm{g} / \mathrm{ml})$ leading to a decrease in $\mathrm{RU}$ values to $32 \pm 7.2$ (for $\mathrm{HBP} \mathrm{F}_{f}$ ) and $48 \pm 17\left(\mathrm{HBP} \mathrm{M}_{f}\right.$ ) for all assayed concentration (data not shown).

The specificity of the binding in the SPR assays was confirmed by negative controls using immobilized BSA on the chip surface. In these control experiments, no significant association and dissociation rates were detected for tests with promastigotes or either protein fractions, as previously described [27].

\section{Discussion}

The Leishmania spp parasites are an important example of protozoans related to human infectious diseases with transmission by arthropods [32,33]. Some current studies on the life cycle of these parasites have emphasized the interaction of promastigotes with gut cells or tissues of sandflies [34,35]. In this context, it has been shown recently that the Lulo cell line can be useful as a model for studies of insect-parasite interactions for Leishmania spp [14], partially simulating the adhesion events that occur in the sandflies gut. In the present study, we show evidence that $65.0 \mathrm{kDa}$ and $55.0 \mathrm{kDa}$ HBPs from the promastigote surface can participate in the adhesion to Lulo cells through HS binding.

The Lulo cell line is composed of epitheloid cells, originated from embryonic tissue of $L u$. longipalpis adult insects, a species which is commonly used in studies of interaction between parasite and insect [36]. Although Lulo cells have already been described as interacting more avidly with $L$. (L.) chagasi promastigotes of $[14,37]$, we provide, in the present study, additional evidence that $L$. $(V$.$) braziliensis has the ability to interact with Lulo cells.$ This is an interesting finding, as Lu. longipalpis has been reported as an efficient vector for species of the subgenera Leishmania and Lulo cells are derived from this sand fly species. Possibly, these data are indicative of the existence of common molecules between the subgenera Viannia and Leishmania, which would be related to promastigote adhesion to the surface of Lulo cells.

Since it is known that glycosaminoglycan-binding microbial proteins interfere in the processes of adhesion and invasion of host tissues [38] and that these proteins have already been described on the surface of $L$. (V.) braziliensis, we considered it would be interesting to evaluate the participation of these proteins in the attachment of promastigotes to Lulo cells. The data gathered in the present study, corroborates the influence of HBPs in the 

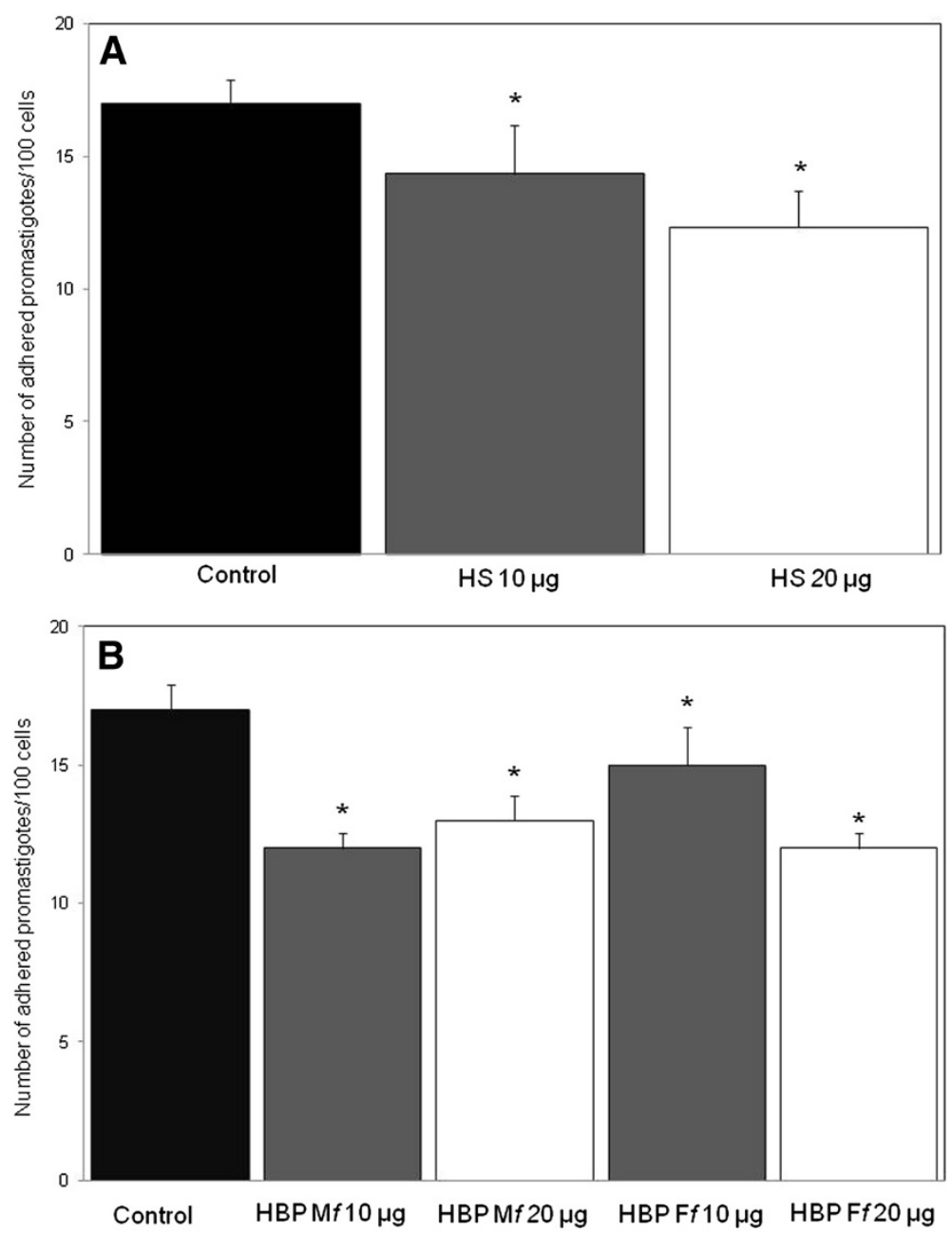

Figure 3 Quantification of promastigote adhesion to Lulo cells. Adhesion inhibition assays were performed using promastigotes without or with pre-incubation with increasing concentrations of heparan sulfate $(\mathbf{A})$ were co-incubated $\left(28^{\circ} \mathrm{C}\right)$ with Lulo cells monolayers. Likewise, Lulo cells monolayers without or with pre-incubation with different concentrations $(10 \mu \mathrm{g}$ and $20 \mu \mathrm{g})$ of HBP $\mathrm{F}_{f}$ and HBP $\mathrm{M}_{f}$, and $20 \mu \mathrm{g}$ of BSA (control) were co-incubated with promastigotes (B). The coverslip containing cells and/or parasites samples were stained with Giemsa and the number of adhered promastigotes/100 cells was determined by light microscopy examining 300 cells per coverslip, in triplicate. Data are expressed as percentile values (\%) and represent average and standard deviation of five independent experiments $-(*), p<0.05$.

promastigote adhesion to Lulo cells, supporting the involvement of parasite surface compounds in the adhesion to host cells $[4,7]$. Although we have previously described that HBPs from flagella have more affinity to bind to heparin [27], the data presented here prove that HBPs from both flagella and membrane fractions are able to participate in the adhesion of promatigotes to the Lulo cell monolayers, interacting with heparan sulfate molecules of these cells. These findings are supported by previous studies that indicate the participation of sulfated glycosaminoglycans in host-parasite recognition processes, as: invasion of hepatocytes by Plasmodium sporozoites through the major surface proteins CSP and TRAP [39,40]; adhesion of Plasmodium sp.infected erythrocytes to the placenta [41]; invasion of mosquito midgut by Plasmodium falciparum [42]; and, adhesion of Trypanosoma epimastigotes to the gut epithelial cells of Rhodnius prolixus [43,44].

Additionally, this study presents the first report of the presence of sulfated glycosaminoglycans, HS and CS, in Lulo cells. Although the present results do not directly specify the localization of these components on the cell surface, the competition assays are indicative of a surface localization of glycosaminoglycans on the Lulo cells. Indeed, the current literature in biochemistry shows that sulfated glycosaminoglycans are ubiquitous among animal cell membranes and are present on the surface of virtually every adherent cell [45] and can modulate the actions of a large number of extracellular ligands [46]. Generally, invertebrates produce the same types of 


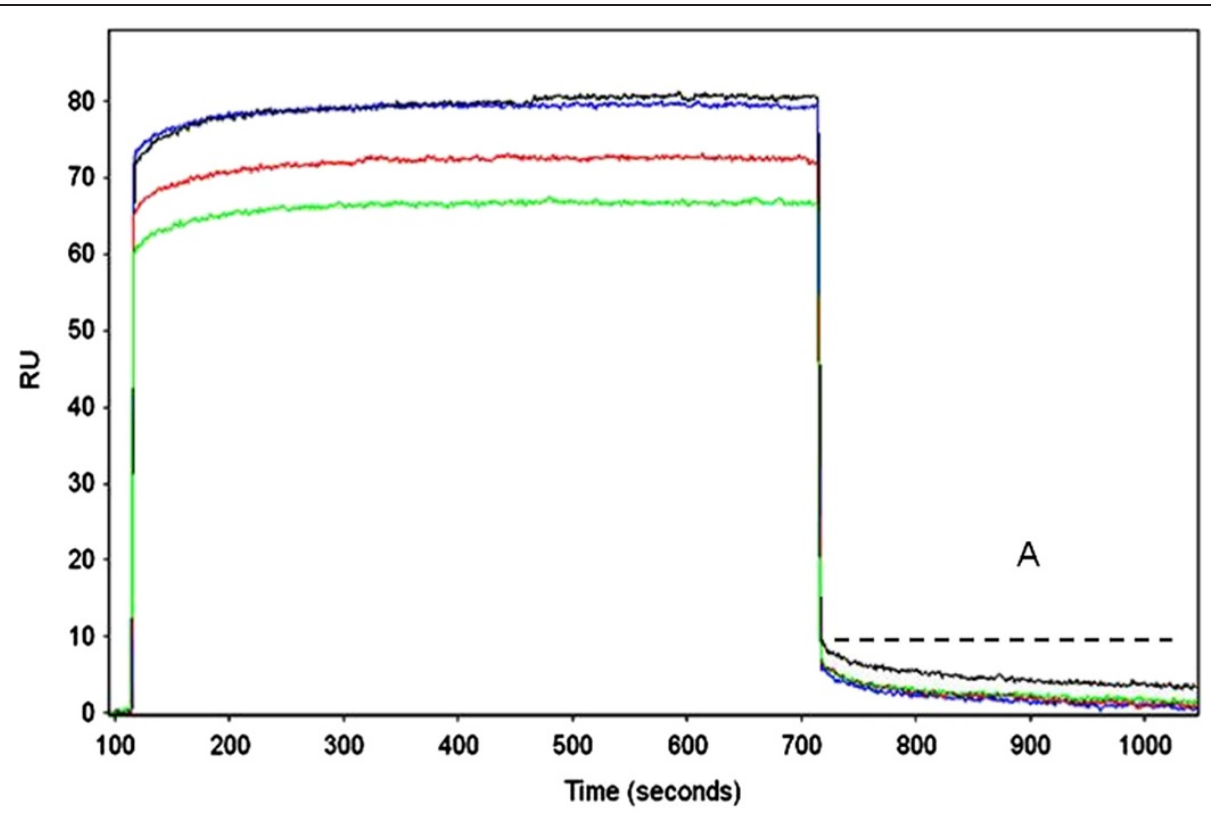

A

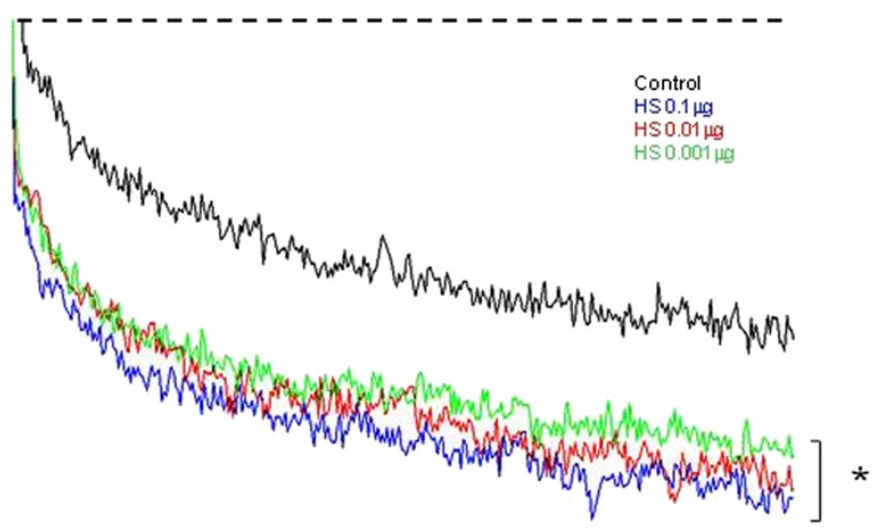

Figure 4 Analysis of Leishmania. (V.) braziliensis promastigotes adhesion to glycosaminoglycans by surface plasmon resonance. Sensor chips were covered with biotinylated heparin, and promastigotes were passed over the chip surface. The parasites were assayed without preincubation with heparan sulfate (black line) or after pre-incubation with $0.001 \mu \mathrm{g}$ (green line), $0.01 \mu \mathrm{g}$ (red line) or $0.1 \mu \mathrm{g}$ (blue line) of heparan sulfate. Significant decrease in adhesion rates was observed in the pre-incubated samples was achieved $-\left(^{*}\right), p<0.05$. Data are presented as arbitrary resonance units (RU) and are representative of two independent experiments. The dissociation $\mathrm{RU}$ values are representative of the average response between 720 and 1020 seconds (A) in all assays.

GAGs as vertebrates, except that hyaluronic acid is not present and chondroitin chains tend to be non-sulfated [18]. Thus, our results add new information to the description of the diversity of GAGs distributed in cells and tissues of invertebrates.

Due to the stability of the HBP-GAG complexes observed in the biosensor analysis, we postulate that HBPs play specific roles in parasite-host interactions. It is the second time we are able to demonstrate the potential of SPR biosensor to prove the surface localization of HBPs on promastigotes. The reduction of the RU values observed in the competition assays with promastigotes or HS reinforced the conclusion that the HBPs can recognize the actual GAGs in the Lulo cells surface, which is in agreement with the Lulo cell-promastigotes interaction data. Moreover, the slow decrease in the sensorgram baseline after interaction of HBP fractions with the heparin-coated chip surface is evidence of the stability of the complex formed between promastigote HBPs and GAGs, as HS.

Biosensing surface procedures have already been used to detect specific proteins on the surface of Trypanosoma cruzi epimastigotes [44] and L. (V.) braziliensis promastigotes [27] and correlate to stable interactions that occur at the interface of these protozoan parasites to their host cells surface. Similar analysis has also been 
conducted to study the interaction of measles virus and heparin in the infection of SLAM-negative cell lines [47] and of Plasmodium circumsporozoite with heparin in liver invasion [48].

The strong binding of $L$. (V.) braziliensis to GAGs observed in the performed physicochemical assays reinforces the putative function of the $65.0 \mathrm{kDa}$ and $55.0 \mathrm{kDa}$ proteins of promastigotes as important adherent compounds in the life cycle of this parasite. In prior studies, proteins with similar molecular masses were isolated by heparin-affinity chromatography methodology and described as hydrophobic proteins of $L$. (V.) braziliensis promastigotes [26]. As we have previously described a $65.0 \mathrm{kDa} \mathrm{HBP}$ of $L$. (V.) braziliensis with metallo proteinase-like properties [27], we hypothesize that this HBP may act as a protagonist of proteolytic activities triggered by the HBPs-GAGs recognition event and thus play a role for the adhesion of the parasite to insect cells. Additionally, it has also been suggested that Leishmania spp parasites could modulate key enzymes or proteins in the gut of the sandfly, therefore obtaining advantages for their establishment and survival in these hosts [49]. Collectively, our data suggest that metallo proteinase from promastigote surfaces are involved in the attachment to Lulo cells via binding of GAGs, as HS. Additional studies will be necessary to further prove this hypothesis and also investigate the biological role of the $55 \mathrm{kDa}$ HBP.

\section{Conclusions}

We have presented evidence that HBPs (with $65.0 \mathrm{kDa}$ and $55.0 \mathrm{kDa}$ ) from the membrane and flagella of $L .(V$.) braziliensis promastigotes have the ability to recognize HS, with stable receptor-ligand interaction. The set of results presented here emphasizes the role of HBPs on promastigote adhesion to the Lulo cells by their GAGs.

\section{Competing interests}

The authors declare that they have no competing interests.

\section{Acknowledgements}

We are thankful for the financial support of PAPES V - CNPq/Fiocruz (300731/2010-8), CNPq (509737/2010-2), CAPES (EDITAL - 11/2009) and FAPERJ (E-26/103.060/2008, E-26/110.257/2010). Luzia M. C. Côrtes, MSc, Francisco O. O. Jr MSC and Franklin S Silva MSC are doctoral student of Fiocruz institution, Bernardo A. S. Pereira PhD is a postdoctoral researcher fellow of CAPES/FAPERJ. Renata S Soares PhD is a postdoctoral researcher fellow of CNPq. Carlos R. Alves PhD, Mirian C. S. Pereira PhD, Helena B. Nader $\mathrm{PhD}$ and Leny Toma are fellow researchers of CNPq institution.

\footnotetext{
Author details

'Laboratório de Biologia Molecular e Doenças Endêmicas, Av. Brasil 4365, Rio de Janeiro - CEP 21040-360, Brazil. 'Laboratório de Ultraestrutura Celular, Av. Brasil 4365, Rio de Janeiro - CEP 21040-360, Brazil. ²Laboratório de Bioquímica e Fisiologia de Insetos - IOC - Fiocruz, Av. Brasil 4365, Rio de Janeiro - CEP 21040-360, Brazil. " Laboratório de Vigilância em Leishmanioses - IPEC - Fiocruz, Av. Brasil 4365, Rio de Janeiro - CEP 21040-360, Brazil. ${ }^{5}$ Departamento de Bioquímica Universidade Federal de São Paulo, UNIFESP, SP, Brazil. ${ }^{6}$ Universidad Del Rosario, Escuela de Medicina, Carrera 24 no 63 C69, Bogotá, D.C, Colombia.
}

\section{Authors' contributions}

LMCC, MCSP and CRA formulated the idea and wrote the manuscript; LMCC, FSS, FOOJ, ROAS, CMV, and MFM performed the experimental assays. BASP, $L T, H B N, R P B$ and FB provided critical comments and participated in protocol drafting, results analysis and discussion construction. All authors approved the final version of this manuscript

Received: 23 February 2012 Accepted: 2 July 2012

Published: 17 July 2012

\section{References}

1. Reithinger R, Dujardin JC, Louzir H, Pirmez C, Alexander B, Brooker S: Cutaneous leishmaniasis. Lancet Infect Dis 2007, 7:581-596.

2. Rangel EF, Lainson R: Ecologia das leishmanioses. Transmissores de leishmaniose tegumentar Americana. In Flebotomíneos do Brasil. Edited by Rangel EF, Lainson R. Rio de Janeiro, Brazil: Fiocruz; 2003:291-309.

3. Kaye P, Scott P: Leishmaniasis: complexity at the host-pathogen interface. Nat Rev Microbiol 2011, 9:604-615.

4. Bates PA, Rogers ME: New insights into the developmental biology and transmission mechanisms of Leishmania. Curr Mol Medicine 2004, 4:601-609.

5. Pimenta PF, Modi GB, Pereira ST, Shahabuddin M, Sacks DL: A novel role for the peritrophic matrix in protecting Leishmania from the hydrolytic activities of the sand fly midgut. Parasitology 1997, 115:359-369.

6. Walters LL, Irons KP, Modi GB, Tesh RB: Refractory barriers in the sand fly Phlebotomus papatasi (Diptera: Psychodidae) to infection with Leishmania panamensis. Am J Trop Med Hyg 1992, 46:211-228.

7. Bates PA: Leishmania sand fly interaction: progress and challenges. Curr Opin Microbiol 2008, 11:340-344.

8. Hajmová M, Chang KP, Kolli B, Volf P: Down-regulation of gp63 in Leishmania amazonensis reduces its early development in Lutzomyia longipalpis. Microbes Infect 2004, 6:646-649.

9. Soares RP, Margonari C, Secundino NC, Macêdo ME, da Costa SM, Rangel EF, Pimenta PF, Turco SJ: Differential midgut attachment of Leishmania (Viannia) braziliensis in the sand flies Lutzomyia (Nyssomyia) whitmani and Lutzomyia (Nyssomyia) intermedia. J Biomed Biotechnol 2010, 2010:439174.

10. Kamhawi S, Modi GB, Pimenta PF, Rowton E, Sacks DL: The vectorial competence of Phlebotomus sergenti is specific for Leishmania tropica and is controlled by species-specific, lipophosphoglycan-mediated midgut attachment. Parasitology 2000, 121(Pt 1):25-33.

11. Pimenta PF, Saraiva EM, Rowton E, Modi GB, Garraway LA, Beverley SM, Turco SJ, Sacks DL: Evidence that the vectorial competence of phlebotomine sand flies for different species of Leishmania is controlled by structural polymorphisms in the surface lipophosphoglycan. Proc Natl Acad Sci USA 1994, 91:9155-9159.

12. Pimenta PF, Turco SJ, McConville MJ, Lawyer PG, Perkins PV, Sacks DL: Stage-specific adhesion of Leishmania promastigotes to the sandfly midgut. Science 1992, 256:1812-1815.

13. Rogers ME, Ilg T, Nikolaev AV, Ferguson MA, Bates PA: Transmission of cutaneous leishmaniasis by sand flies is enhanced by regurgitation of fPPG. Nature 2004, 430:463-467.

14. Côrtes LM, Silva RM, Pereira BA, Guerra C, Zapata AC, Bello FJ, Finkelstein LC, Madeira MF, Brazil RP, Corte-Real S, Alves CR: Lulo cell line derived from Lutzomyia longipalpis (Diptera: Psychodidae): a novel model to assay Leishmania spp. and vector interaction. Parasit Vectors 2011, 4:216.

15. Naderer T, Vince JE, McConville MJ: Surface determinants of Leishmania parasites and their role in infectivity in the mammalian host. Curr Mol Med 2004, 4:649-665.

16. Garcia ES, Azambuja P, Nader HB, Dietrich CP: Biosynthesis of sulfated glycosaminoglycans in the hemipteran Rhodnius prolixus. Insect Biochemistry 1986, 16:347-352.

17. Toledo OMS, Dietrich CP: Tissue specific distribution of sulfated mucopolysaccharides in mammals. Biochim Biophy Acta 1977, 498:114-122.

18. Jeffrey D, Esko Robert J, Linhardt: Proteins that bind sulfated glycosaminoglycans. In Essentials of glycobiology. 2nd edition. Edited by Varki A, Cummings RD, Esko JD, et al. Cold Spring Harbor (NY): Cold Spring Harbor Laboratory Press; 2009.

19. Alves CR, Silva FS, Oliveira-Junior FO, Pereira BAS, Pires FA, Pereira MCS: Affinity-based methods for the separation of parasite proteins. In Affinity Chromatography:: In Tech (in press); 2012. 
20. Love DC, Esko JD, Mosser DM: A heparin-binding activity on Leishmania amastigotes which mediates adhesion to cellular proteoglycans. J Cell Biol 1993, 123:759-766

21. Volf P, Svobodova M, Dvorakova E: Blood meal digestion and Leishmania major infections in Phlebotomus duboscqi: effect of carbohydrates inhibiting midgut lectin activity. Med Vet Entomol 2001, 15:281-286.

22. Mukhopadhyay NK, Shome K, Saha AK, Hassell JR, Glew RH: Heparin binds to Leishmania donovani promastigotes and inhibits protein phosphorylation. Biochem J 1989, 264:517-525.

23. Butcher BA, Shome K, Estes LW, Choay J, Petitou M, Sie P, Glew RH: Leishmania donovani: cell-surface heparin receptors of promastigotes are recruited from an internal pool after trypsinization. Exp Parasitol 1990, 71:49-59.

24. Butcher BA, Sklar LA, Seamer LC, Glew RH: Heparin enhances the interaction of infective Leishmania donovani promastigotes with mouse peritoneal macrophages. A fluorescence flow cytometric analysis. J Immunol 1992, 148:2879-2886.

25. Kock NP, Gabius HJ, Schmitz J, Schotteliu J: Receptors for carbohydrate ligands including heparin on the cell surface of Leishmania and other trypanosomatids. Trop Med Int Health 1997, 2:863-874.

26. Azevedo-Pereira RL, Pereira MCS, Oliveira FOR Jr, Brazil RP, Côrtes LMC, Madeira MF, Santos ALS, Toma L, Alves CR: Heparin binding proteins from Leishmania (Viannia) braziliensis promastigotes. Vet Parasitol 2007, 145:234-239.

27. De Castro Côrtes LM, de Souza Pereira MC, de Oliveira FO Jr, Corte-Real S, da Silva FS, Pereira BA, de Fátima Madeira M, de Moraes MT, Brazil RP, Alves CR: Leishmania (Viannia) braziliensis: insights on subcellular distribution and biochemical properties of heparin-binding proteins. Parasitology 2012, 7:1-8.

28. Lowry OH, Rosebrough NJ, Farr AL, Randall RJ: Protein measurement with the Folin phenol reagent. J Biol Chem 1951, 193:265-275.

29. Laemmli UK: Cleavage of structural proteins during the assembly of the head of bacteriophage T4. Nature 1970, 227:680-685.

30. Gonçalves AM, Nehme NS, Morel CM: An improved silver staining procedure for schizodeme analysis in polyacrylamide gradient gels. Mem Inst Oswaldo Cruz 1990, 85:101-106.

31. Dietrich CP, Dietrich SM: Electrophoretic behavior of acidic mucopolysaccharides in diamine buffers. Anal Biochem 1976, 70:645-647.

32. Romi R: Arthropod-borne diseases in Italy: from a neglected matter to an emerging health problem. Ann Ist Super Sanita 2010, 46:436-443.

33. Williams CR, Bader CA, Kearney MR, Ritchie SA, Russel RC: The extinction of dengue through natural vulnerability of its vectors. PLoS Negl Trop Dis 2010, 4:e922.

34. Handman E: Cell biology of Leishmania. Adv Parasitol 1999, 44:1-39.

35. Wilson R, Bates MD, Dostalova A, Jecna L, Dillon RJ, Volf P, Bates PA: Stagespecific adhesion of Leishmania promastigotes to sand fly midguts assessed using an improved comparative binding assay. PLoS Negl Trop Dis 2010, 4(pii):e816.

36. Rey G, Ferro C, Bello F: Establishment and characterization of a new continuous cell line from Lutzomyia longipalpis (Diptera: Psychodidae) and its susceptibility to infections with arboviruses and Leishmania chagasi. Mem Inst Oswaldo Cruz 2000, 95:103-110.

37. Bello FJ, Mejía AJ, Corena MP, Ayala M, Sarmiento L, Zúñiga C, Palau MT: Experimental infection of Leishmania (L.) chagasi in a cell line derived from Lutzomyia longipalpis (Diptera: Psychodidae). Mem Inst Oswaldo Cruz 2005, 100:619-625.

38. Wadström T, Ljungh A: Glycosaminoglycan-binding microbial proteins in tissue adhesion and invasion: key events in microbial pathogenicity. J Med Microbiol 1999, 48:223-233.

39. Coppi A, Tewari R, Bishop JR, Bennett BL, Lawrence R, Esko JD, Billker O, Sinnis P: Heparan sulfate proteoglycans provide a signal to Plasmodium sporozoites to stop migrating and productively invade host cells. Cell Host \& Microbe 2007, 2:316-327.

40. Pradel G, Garapaty S, Frevert U: Proteoglycans mediate malaria sporozoite targeting to the liver. Mol Microbiol 2002, 45:637-651.

41. Nunes MC, Scherf A: Plasmodium falciparum during pregnancy: a puzzling parasite tissue adhesion tropism. Parasitology 2007, 134:1863-1869.

42. Dinglasan RR, Alaganan A, Ghosh AK, Saito A, van Kuppevelt TH, JacobsLorena M: Plasmodium falciparum ookinetes require mosquito midgut chondroitin sulfate proteoglycans for cell invasion. Proc Natl Acad Sci U S A 2007, 104:15882-15887.
43. Gonzalez MS, Hamedi A, Albuquerque-Cunha JM, Nogueira NF, De Souza W, Ratcliffe NA, Azambuja P, Garcia ES, Mello CB: Antiserum against perimicrovillar membranes and midgut tissue reduces the development of Trypanosoma cruzi in the insect vector, Rhodnius prolixus. Exp Parasitol 2006, 114:297-304.

44. Oliveira-Jr FOR, Alves CR, Souza-Silva F, Calvet CM, Côrtes LMC, Gonzalez MS, Toma L, Bouças RI, Nader HB, Pereira MCS: Trypanosoma cruzi heparin-binding proteins mediate the adherence of epimastigotes to the midgut epithelial cells of Rhodnius prolixus. Parasitology 2012, 139:735-743.

45. Dietrich CP, Montes de Oca H: Surface sulfated mucopolysaccharides of primary and permanent mammalian cell lines. Biochem Biophys Res Commun 1978, 80:805-812.

46. Bernfield M, Götte M, Park PW, Reizes O, Fitzgerald ML, Lincecum J, Zako M: Functions of cell surface heparan sulfate proteoglycans. Annu Rev Biochem 1999, 68:729-777.

47. Terao-Muto Y, Yoneda M, Seki T, Watanabe A, Tsukiyama-Kohara K, Fujita K, Kai C: Heparin-like glycosaminoglycans prevent the infection of measles virus in SLAM negative cell lines. Antiviral Res 2008, 80:370-376.

48. Rathore D, McCutchan TF, Garboczi DN, Toida T, Hernáiz MJ, LeBrun LA, Lang CS, Linhardt RJ: Direct measurement of the interactions of glycosaminoglycans and a heparin decasaccharide with the malaria circumsporozoite protein. Biochemistry 2001, 40:11518-11524.

49. Ramalho-Ortigão M, Jochim RC, Anderson JM, Lawyer PG, Pham VM, Kamhawi S, Valenzuela JG: Exploring the midgut transcriptome of Phlebotomus papatasi: comparative analysis of expression profiles of sugar-fed, blood-fed and Leishmania-major-infected sandflies. BMC Genomics 2007, 8:300.

doi:10.1186/1756-3305-5-142

Cite this article as: de Castro Côrtes et al:: Participation of heparin binding proteins from the surface of Leishmania (Viannia) braziliensis promastigotes in the adhesion of parasites to Lutzomyia longipalpis cells (Lulo) in vitro. Parasites \& Vectors 2012 5:142.

\section{Submit your next manuscript to BioMed Central and take full advantage of:}

- Convenient online submission

- Thorough peer review

- No space constraints or color figure charges

- Immediate publication on acceptance

- Inclusion in PubMed, CAS, Scopus and Google Scholar

- Research which is freely available for redistribution 